\title{
Slys meðal sjómanna á Íslandi árin 2001-2005
}

Kristinn

Sigvaldason ${ }^{1}$

svæfinga- og gjörgæslulæknir

Friðrik Pór

Tryggvason $^{2}$

læknanemi

Guơrún

Pétursdóttir ${ }^{3}$

lífeðlisfræðingur

Hilmar

Snorrason ${ }^{4}$

skólastjóri

Halldór

Baldursson ${ }^{5}$

tryggingalæknir

Brynjólfur

Mogensen ${ }^{2,6}$

bráðalæknir

Lykilorð: slys, sjómenn, fiskiskip, banaslys, áverkastig.

\section{Ágrip}

Tilgangur: Sjómennskan er eitt hættulegasta starf samfélagsins. Árin 1966-1989 létust 89/100.000 sjómenn/ári á Íslandi. Markmið rannsóknarinnar var að kanna í forvarnarskyni aðdraganda og umfang slysa á sjó við Ísland á árunum 2001-2005. Efniviður og aðferðir: Kannaðar voru tilkynningar til rannsóknarnefndar sjóslysa og Tryggingastofnunar ríkisins og yfirfarin NOMESCO slysaskrá á bráđamóttöku Landspítala. Par eru upplýsingar um orsakir slyss, áverka, starfsreynslu hins slasaða, veðurlag, sjólag, tegund veiða, tegund skips og fleira. Metin var áverkaskor innlagðra (Injury Severity Score).

Niðurstöður: Á tímabilinu urðu 17 banaslys, par af 14 starfstengd, sem jafngildir 54/100.000 sjómönnum/ári. Tryggingastofnun bárust 1787 tilkynningar, að meðaltali 357 á ári (7\% starfandi sjómanna). Alls voru 223 metnir til varanlegrar örorku (meðaltal 14,7\%). Til slysa- og bráðadeildar Landspítala leituðu 826, 52 voru lagðir inn og var áverkaskor peirra að meðaltali 5,5 (1-16). Flest slysin (87\%) urðu á fiskiskipum, par af $51 \%$ á togurum. Slysin urðu oftast í góðu veðri, við dagsbirtu og hjá reyndum sjómönnum. Algengastir voru áverkar á útlimum, sérstaklega á höndum.

Ályktun: Slys eru tíð meðal sjómanna en banaslysum hefur fækkað talsvert síðustu áratugi. Flest slys verða á fiskiskipum við góðar aðstæður hjá reyndum sjómönnum sem bendir til pess að huga purfi að vinnuaðferðum um borð.

\section{Inngangur}

Fiskveiðar eru ein af undirstöðuatvinnugreinum Íslendinga par sem sjávarafurðir voru $42 \%$ af útflutningsverðmætum pjóðarinnar árið $2007 .{ }^{1}$ Sjómannsstarfið er pví pjóðhagslega afar mikilvægt par sem umfangsmiklar fiskveiðar eru stundaðar við Ísland auk pess sem miklir millilandaflutningar eiga sér stað allt árið um kring. Um 2000 skip og bátar eru skráo á Íslandi, flest fiskiskip, en um 5000 manns hafa atvinnu á sjó hérá landi, auk íslenskra kaupskipasjómanna sem sigla að og frá landinu á erlendum skipum. Samkvæmt erlendum rannsóknum er sjómannsstarfið talið pað hættulegasta í samfélaginu, par sem skráð tíðni banaslysa er oftast hæst í peirri starfssétt eða um 100-400 af hverjum 100.000 sjómönnum sem starfa við fiskveiðar. ${ }^{2-4}$ Tíðni banaslysa á kaupskipum er mun lægri eða 37-45 af hverjum 100.000 starfandi sjómönnum á ári. ${ }^{5,6}$ Samkvæmt íslenskri rannsókn tímabilið 1966-1986 létust 89 af hverjum 100.000 sjómönnum árlega við störf sín og sjómönnum er einnig hættara en öðrum starfsstéttum við að bíða bana í slysum eftir að í land er komið. Slysavarnir hafa pó borið árangur par sem banaslysum fækkaði á tímabilinu 19802005 úr 15 í 2,4 á ári. ${ }^{8}$

Tíðni vinnuslysa, annarra en banaslysa, er einnig mun hærri hjá sjómönnum en í flestum öðrum starfsgreinum. ${ }^{9}$ Samkvæmt skýrslu frá Evrópusambandinu er tíoni vinnuslysa sem leiða til meira en priggja daga vinnutaps hæst við fiskveiðar eða um 2,4 sinnum algengari en hjá verkamönnum í byggingarvinnu sem talin er hættulegasta starfsgreinin í landi. ${ }^{10}$ Slys um borð í fiskiskipum verða oftast við meðhöndlun veiðarfæra. ${ }^{2,9}$ Ekki hafa verið birt gögn um slys önnur en banaslys hjá íslenskum sjómönnum.

Pegar pessi rannsókn var gerð voru slys á sjó skráð skipulega á premur stöðum á Íslandi. Skylt er samkvæmt lögum að tilkynna öll slys á sjó til rannsóknarnefndar sjóslysa (RNS). Bótaskyld vinnuslys parf að tilkynna til Tryggingastofnunar ríkisins (TR) og pá purfa að fylgja með upplýsingar um aðdraganda og aðstæður slyssins. Á slysa- og bráðadeild Landspítala eru allar komur vegna slysa skráðar samkvæmt norræna slysaskráningarkerfinu (NOMESCO) en par er að finna sérstakan íslenskan undirflokk fyrir slys á sjó par sem ýtarlega er greint frá orsök, aðdraganda og ytri aðstæðum er slysið varð.

Tilgangur rannsóknarinnar var að kanna umfang slysa á sjómönnum hér á landi árin 20012005 með pví að yfirfara pessar skráningar, afla sem bestra upplýsinga um orsakir og við hvaða aðstæður slysin urðu og hvaða afleiðingar pau höfðu í för með sér. Slíkar upplýsingar mætti nýta í forvarnarstarfi til að auka öryggi sjófarenda. 
Tafla I. Slys međal sjómanna á Íslandi 2001-2005. Taflan sýnir yfirlit yfir banaslys tilkynnt til Rannsóknarnefndar sjóslysa, bótaskyld slys tilkynnt til Tryggingastofnunar ríkisins (TR) og komur á Landspitala vegna slysa á sjó tímabilið 2001-2005. Einnig eru gefin meðaltöl fyrir allt tímabilið.

\begin{tabular}{|c|c|c|c|c|c|c|c|}
\hline Ár & 2001 & 2002 & 2003 & 2004 & 2005 & Samtals & Meðaltal \\
\hline \multicolumn{8}{|l|}{ Banaslys } \\
\hline Fjöldi starfandi sjómanna & 6000 & 5300 & 5100 & 4600 & 5100 & & 5220 \\
\hline Fjöldi banaslysa & 7 & 2 & 2 & 3 & 3 & 17 & 3,4 \\
\hline Banaslys/105 starfandi sjómenn/ár & 117 & 38 & 39 & 43 & 20 & & 64 \\
\hline \multicolumn{8}{|l|}{ Tilkynningar til TR } \\
\hline $\begin{array}{l}\text { Fjöldi tilkynninga til TR vegna slysa } \\
\text { á sjómönnum }\end{array}$ & 336 & 395 & 364 & 333 & 359 & 1787 & 357 \\
\hline $\begin{array}{l}\text { Par af mál sem enduðu með } \\
\text { örorkumati }\end{array}$ & 36 & 44 & 46 & 56 & 41 & 223 & 45 \\
\hline $\begin{array}{l}\text { Tí́ni slysa annarra en banaslysa } \\
\text { fyrir hverja } 10^{5} \text { starfandi sjómenn/ár }\end{array}$ & 5600 & 7453 & 7137 & 7239 & 7039 & & 6894 \\
\hline $\begin{array}{l}\text { Hlutfall tilkynninga af fjölda } \\
\text { starfandi sjómanna }\end{array}$ & 5,6 & 7,5 & 7,1 & 7,2 & 7,0 & & 6,8 \\
\hline \multicolumn{8}{|l|}{ Komur á Landspítala } \\
\hline $\begin{array}{l}\text { Fjöldi koma á bráđamóttöku } \\
\text { vegna slysa á sjó }\end{array}$ & 170 & 145 & 191 & 163 & 157 & 826 & 165,2 \\
\hline $\begin{array}{l}\text { Hlutfall koma af fjölda starfandi } \\
\text { sjómanna }\end{array}$ & 2,8 & 2,7 & 3,7 & 3,5 & 3,1 & & 3,2 \\
\hline Fjöldi innlagna & 8 & 5 & 18 & 9 & 12 & 52 & 10,4 \\
\hline Hlutfall innlagna af komum & 4,7 & 3,4 & 9,4 & 5,5 & 7,6 & & 6,1 \\
\hline $\begin{array}{l}\text { Hlutfall innlagna af fjölda starfandi } \\
\text { sjómanna }\end{array}$ & 0,1 & 0,1 & 0,4 & 0,2 & 0,2 & & 0,2 \\
\hline Komur $/ 10^{5}$ starfandi/ár & 2833 & 2736 & 3745 & 3543 & 3078 & & 3187 \\
\hline
\end{tabular}

\section{Efniviður og aðferðir}

Að fengnu leyfi Persónuverndar og Vísindasiðanefndar var farið yfir öll slysatilvik á árunum 2001-2005 sem skráð voru hjá RNS, TR eða i norræna slysaskráningarkerfið sem komur vegna slysa á sjó. Við athugun á banaslysum á sjó var notast við skýrslur RNS um banaslys sem orðið hafa um borð í skipum og bátum í

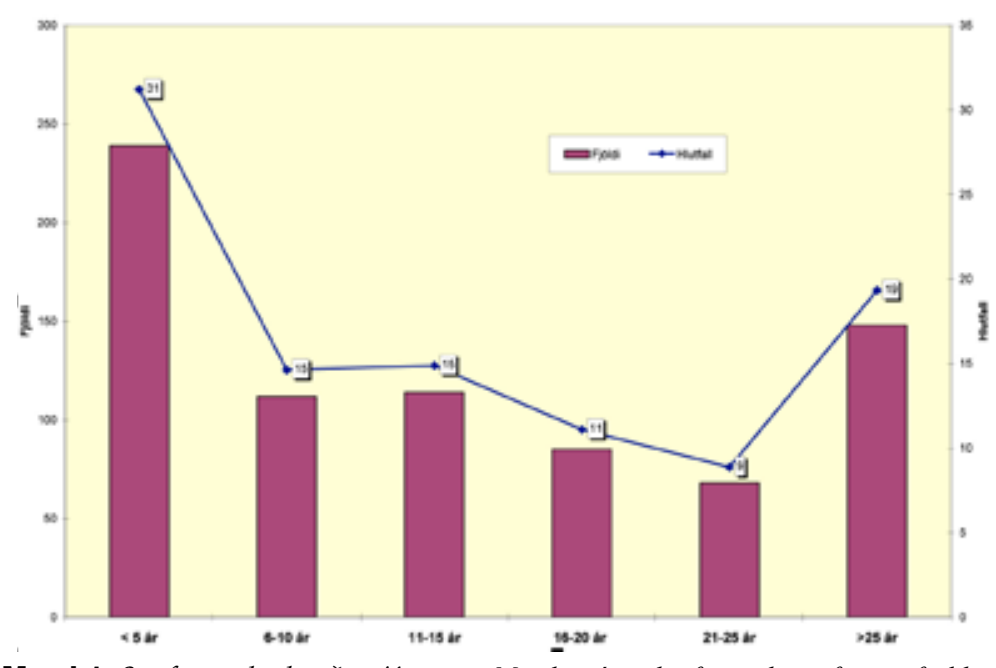

Mynd 1. Starfsreynsla slasaðra sjómanna. Myndin sýnir dreifingu slysa eftir starfsaldri slasaðra. Banaslys eru ekki tekin með. Stcersti einstaki hópurinn hefur minna en 5 ára starfsreynslu en meirihluti slasaðra (70\%) hefur yfir 5 ára starfsreynslu. íslenskri eigu. Hjá TR fengust upplýsingar um fjölda tilkynninga vegna bótaskyldra slysa hjá sjómönnum, fjölda peirra sem metnir voru til varanlegrar læknisfræðilegrar örorku og hversu mikil hún var. Úr norræna slysaskráningarkerfinu sem er framvirk skráning fengust upplýsingar um tímasetningu slyss, tegund skips, aðgerð skips pegar slys átti sér stað, upplýsingar um veðurfar (vindhraða, skyggni, úrkomu, sjólag), starfsreynslu hins slasaða og hvort slysið leiddi til innlagnar á sjúkrahús. Ennfremur var skráð hvar í skipinu slysið varð, orsök, ytri aðstæður og hvaða líkamssvæði varð fyrir áverka. Fyrir pá sem lögðust inn á sjúkrahús vegna áverka var reiknað áverkaskor samkvæmt ISS-kerfi (injury severity score) ${ }^{11}$ par sem líkamanum er skipt í sex svæði og gefin 1-6 áverkastig (abbreviated injury scale) fyrir hvert peirra eftir alvarleika áverka. Stig priggja mest slösuðu líkamssvæðanna eru síðan hafin upp í annað veldi og lögð saman. ${ }^{12}$ Samkvæmt ISS-kerfinu teljast $\leq 3$ stig lítill áverki, 4-8 stig meðaláverki, 9-15 stig mikill áverki, 1624 stig alvarlegur áverki, $\geq 25$ stig lífshættulegur áverki en við 75 stig eru lífslíkur engar og áverkar leiða til dauða.

Upplýsingar um fjölda manna starfandi við fiskveiðar á árunum 2001-2005 eru fengnar úr vinnumarkaðsrannsókn Hagstofu Íslands og eru 
birtar par með öðrum hagtölum á heimasíðu Hagstofunnar. ${ }^{13}$ Rannsóknargögn voru unnin með Excel töflureikni.

\section{Niðurstöður}

Rannsóknarnefnd sjóslysa

Til rannsóknarnefndar sjóslysa voru tilkynnt samtals 17 banaslys á sjó umhverfis Ísland á árunum 2001-2005 eða að meðaltali 3,4 á ári. Tíðni banaslysa á tímabilinu var pví 64 á hverja 100.000 starfandi sjómenn á ári (tafla I). Í tengslum við fiskveiðar létust 13 (76,5\%), einn lést við pangskurð en prír voru ekki starfandi sjómenn. Ef einungis eru tekin starfstengd banaslys, sem voru 14, var tíðni banaslysa að meðaltali 54 af hverjum 100.000 starfandi sjómönnum á ári. Banaslysin 17 urðu á 12 skipum en 11 drukknuðu pegar sex skipanna fórust, tveir féllu útbyrðis og tveir drukknuðu í höfn. Tveir létust af áverkum eftir slys um borð. Engin banaslys urðu á kaupskipum á tímabilinu.

\section{Tryggingastofnun ríkisins}

Árin 2001-2005 voru 1787 slys á sjómönnum tilkynnt til Tryggingastofnunar ríkisins (TR) eða að meðaltali 357 á ári. Hlutfall slasaðra af starfandi sjómönnum reyndist vera svipað öll árin eða um 7\% (tafla I). Alls voru 223 sjómenn metnir til örorku eftir vinnuslys, par af 46 með 19\% örorku, 173 með 10-49\% örorku og fjórir með $50-70 \%$ örorku. Meðaltal örorkumats var $14,7 \%$ og miðgildi var $12 \%$.

\section{Slysa og brádadeild Landspitala}

Á slysa- og bráđadeild Landspítala voru skráđar 826 komur vegna slysa á sjó (tafla I) á tímabilinu eða að meðaltali 165 sjómenn á ári og um 3,2\% starfandi sjómanna. Af pessum 826 voru 84 erlendir ríkisborgarar (10\%). Meðalaldur var 37 ár (8-80 ár). Eftir komu á slysa- og bráðadeild voru 52 sjómenn lagðir inn á Landspítala eða $6,2 \%$ af peim sem pangað leituðu. Legutími á sjúkrahúsi var að meðaltali 2,7 dagar (1-21 dagur). Prír innlagðra sjúklinga voru ekki með áverka sem hægt var að meta með áverkaskori (tvær ofkælingar, ein eitrun). Áverkaskor 49 innlagðra var að meðaltali 5,5 stig (1-16 stig) og miðgildið var fjórir. Samkvæmt áverkaskori var áverki lítill eða í meðallagi hjá 34 (70\%), mikill hjá 14 (29\%) og einn var með alvarlega áverka. Enginn var metinn með lífshættulega áverka og enginn af peim sem komust á sjúkrahúsið lést á tímabilinu.

Tæplega 70\% slasaðra sjómanna reyndust hafa meira en fimm ára starfsreynslu en stærsti einstaki aldurshópurinn hafði pó starfsreynslu undir fimm árum (mynd 1).
Tafla II. Störf sem unnin eru pegar slys verða um borð í skipum. Banaslys eru ekki talin með. Algengast er að slys verði við meðhöndlun veiðarfæra.

\begin{tabular}{|c|c|c|c|c|c|c|}
\hline \multirow[b]{2}{*}{ Starf } & \multicolumn{2}{|c|}{$\begin{array}{l}\text { Slys um borð i } \\
\text { fiskiskipum }\end{array}$} & \multicolumn{2}{|c|}{$\begin{array}{l}\text { Slys um borð í } \\
\text { öðrum skipum }\end{array}$} & \multicolumn{2}{|c|}{$\begin{array}{c}\text { Allar komur vegna } \\
\text { slysa á sjó }\end{array}$} \\
\hline & Fjöldi & Hlutfall & Fjöldi & Hlutfall & Fjöldi & Hlutfall \\
\hline Taka inn veiðarfæri & 183 & 27,6 & 5 & 5,6 & 188 & 22,8 \\
\hline Viðhaldsvinna & 77 & 11,6 & 26 & 28,9 & 103 & 12,5 \\
\hline Vinnsla á afla um borð & 89 & 13,4 & 1 & 1,1 & 90 & 10,9 \\
\hline Ganga frá fiski í lest & 64 & 9,7 & 1 & 1,1 & 65 & 7,9 \\
\hline Slaka veiðarfærum & 58 & 8,8 & & 0,0 & 58 & 7,0 \\
\hline Losun og lestun & 38 & 5,7 & 13 & 14,4 & 51 & 6,2 \\
\hline Vinna í eldhúsi og prif & 36 & 5,4 & 7 & 7,8 & 43 & 5,2 \\
\hline Viðhald veiðarfæra & 41 & 6,2 & & 0,0 & 41 & 5,0 \\
\hline Frívakt & 27 & 4,1 & 8 & 8,9 & 35 & 4,2 \\
\hline Hífingar & 25 & 3,8 & 5 & 5,6 & 30 & 3,6 \\
\hline Landfestar & 13 & 2,0 & 6 & 6,7 & 19 & 2,3 \\
\hline Varðstaða & 6 & 0,9 & 10 & 11,1 & 16 & 1,9 \\
\hline Ferðir milli skipa & 5 & 0,8 & 8 & 8,9 & 13 & 1,6 \\
\hline Samtals & 662 & & 90 & & 752 & 100,0 \\
\hline
\end{tabular}

Tegund skipa, tegund veiða og slysstaður um borð Alls reyndust $717(87 \%)$ peirra sem leituðu til slysa- og bráðadeildar hafa slasast um borð í fiskiskipum og leiddu 48 slysanna til innlagnar eða 7\%. Af flutningaskipum komu 52 (6,3\%), farpegaskipum $14(1,7 \%)$, varðskipum $11(1,3 \%)$, pjónustuskipum 19 (2,3\%) og af öðrum skipum $13(1,6 \%)$. Vegna slysa um borð í skipum öðrum en fiskiskipum komu pví 109 og voru fjórir peirra lagðir inn eða 3,6\%. Af pessum fjórum komu tveir vegna slysa á farpegaskipum, einn af hraðbáti og einn af seglskútu.

Af slysum um borð í fiskiskipum urðu 366 (51\%) við togveiðar, 102 (14\%) línuveiðar, 93 (13\%) netaveiðar, 33 (5\%) dragnótaveiðar, 20 (3\%) nótaveiðar, 18 (3\%) rækjuveiðar en 11\% við annars konar veiðar en hér eru taldar. Tafla II sýnir að langflest slys verða pegar veiðarfæri eru dregin inn $(28 \%)$ en algengar orsakir eru einnig viðhaldsvinna og frágangur á afla um borð. Í öðrum skipum en fiskiskipum verða slys oftast við viðhaldsvinnu (29\%).

Tafla III sýnir að flest slys verða á pilfari skips eða 395 (46\% af komum, en 53\% ef fiskiskip eru tekin sérstaklega) en slys virðast einnig vera tíð í vinnslurými $(11,5 \%)$ og lest (11\%).

\section{Veðurlag, sjólag og ytri aðstæður}

Í flestum tilfellum (95\%) var skráð veðurlag pegar slysið átti sér stað, eins og vindhraði, sjólag, úrkoma og skyggni. Pegar slysið varð var vindhraði $<5 \mathrm{~m} / \mathrm{s}$ í 501 tilfelli (63\%), 5-10 m/s í 124 tilfellum (15,6\%), 11-15 m/s í 99 tilfellum (12,5\%), 
Tafla III. Slysstaður um borð í skipum. Hér eru ekki tekin með banaslys. Flest slys verða á pilfari skipa.

\begin{tabular}{|c|c|c|c|c|}
\hline Staðsetning & Fjöldi slysa í fiskiskipum & Fjöldi slysa í öðrum skipum & Alls & Hlutfall (\%) \\
\hline Pilfar & 356 & 39 & 395 & 45,8 \\
\hline Vinnslurými & 89 & 2 & 91 & 11,5 \\
\hline Lest & 84 & 7 & 91 & 10,8 \\
\hline Vélarúm & 25 & 7 & 32 & 3,2 \\
\hline Aðgerðarrými & 23 & 1 & 24 & 3,0 \\
\hline Eldhús og búr & 19 & 4 & 23 & 2,4 \\
\hline Gangur & 16 & 9 & 25 & 2,1 \\
\hline Íbúđir / Káetur & 16 & 4 & 20 & 2,1 \\
\hline Pilfarshús & 15 & & 15 & 1,9 \\
\hline Stigar & 11 & 4 & 15 & 1,4 \\
\hline Stjórnpallur & 9 & 9 & 18 & 1,2 \\
\hline Utan skips & 7 & 8 & 15 & 0,9 \\
\hline Geymslur & 6 & 1 & 7 & 0,8 \\
\hline Kranar & 2 & & 2 & 0,3 \\
\hline Tankarými & 1 & 2 & 3 & 0,1 \\
\hline Möstur & 1 & & 1 & 0,1 \\
\hline Ekki skráð & & & 49 & 5,9 \\
\hline Samtals & 680 & 97 & 826 & \\
\hline
\end{tabular}

$16-20 \mathrm{~m} / \mathrm{s}$ í 60 tilfellum $(7,5 \%)$ og > $20 \mathrm{~m} / \mathrm{s}$ í 11 tilfellum $(1,4 \%)$. Meirihluti slysa $(78 \%)$ varð í lítilli eða engri úrkomu og um $60 \%$ slysa urðu í dagsbirtu. Eins og sést á mynd 2 varð meirihluti slysa í fremur lygnum sjó. Í 86\% tilfella var skráð hvort um ytri orsakir hafi verið að ræða, en 75\% slasaðra töldu engar ytri orsakir hafa átt pátt í slysinu og aðeins 19\% tilgreindu sjólag sem ytri orsök. Í 92\% tilfella var tíma- og dagsetning skráð. Flest slys urðu að degi til milli kl. 10 og 18 og náði slysatíðni hámarki milli kl. 14 og 16. Slysatíðni var hæst í febrúar og mars en lægst í sumarmánuðum og í desember.

\section{Tegundir áverka}

Eins og kemur fram í töflu IV verður meirihluti áverka vegna höggs (53\%), annaðhvort við árekstur eða fall, en klemma eða kramning er einnig algeng orsök. Alls voru skráðir 906 áverkar eftir 817 slys. Í 89 tilfellum voru áverkar á fleiri en einu svæði. Níu peirra sem komu voru ekki með áverka sem hægt var að flokka á pennan hátt (rafsuðublinda, eitranir, svimi, ofkæling). Áverkar á útlimum voru $71 \%$ allra áverka, áverkar á höfuð og háls 5\%, brjóstholsáverkar 9\%, hryggjaráverkar $7,6 \%$, áverkar á andliti eða augum 6,8\%, kviðarholsáverkar $1 \%$ og mjaðmagrindaráverkar $0,2 \%$. Áverkar á hendur neðan úlnliðs voru algengastir eða í 34\% tilfella. Áverkar á höndum reyndust algengari um borð í fiskiskipum (37\%) en öðrum skipum (20\%) en skipting áverka eftir líkamssvæðum var svipuð að öðru leyti milli fiskiskipa og annarra skipa. Í samanburði við heildarhópinn reyndist hópurinn sem purfti innlögn á Landspítala ekki frábrugðinn hvað varðar áverkamynstur, tegund veiða, veðurlag, sjólag eða aðra ytri pætti.

\section{Umræða}

Pegar niðurstöður pessarar rannsóknar eru bornar saman við eldri rannsóknir sést að banaslysum á sjó hefur fækkað mjög síðustu áratugi. Flest banaslys verða pegar skip farast og pau voru 89 á hverja 100.000 starfandi sjómenn árin 1966-1986 en reynast nú vera 54 á hverja 100.000 starfandi sjómenn að meðaltali á ári. Tíðni banaslysa lækkaði úr 15 í 2,4 á ári tímabilið 1980 til 2005. ${ }^{8}$ Umtalsverður árangur virðist pví hafa náđst í slysavörnum sjómanna undanfarna fjóra áratugi. Ætla má að menntun skipstjórnarmanna og pjálfun sjómanna í Slysavarnaskóla sjómanna hafi skilað góðum árangri, en ýmsir aðrir pættir gætu skipt hér máli, eins og bætt pyrlubjörgunarpjónusta, framfarir í veðurfræði og veðurspám, framfarir í siglingatækni og almennt betri skip. Hjá Siglingastofnun hefur undanfarin ár verið unnið markvisst að pví að mæla stöðugleika skipa og lagfæra ef eitthvað hefur fundist athugavert og telja menn að pað hafi skilað árangri. ${ }^{14}$

Tíðni banaslysa á sjó er pó enn há í samanburði við vinnutengd banaslys í landi. Starfstengd banaslys hjá 5220 sjómönnum eru 14 á sama tímabili og tilkynnt eru 12 dauðsföll vegna vinnuslysa meðal allra starfsgreina í landi. ${ }^{15,}{ }^{16}$ Í samanburði við niðurstöður erlendra rannsókna virðast starfstengd banaslys á sjó vera álíka tíð hér á landi og pau eru í Ástralíu (56/100.000) og Noregi (68/100.000). ${ }^{9}$

Tíðni annarra slysa en banaslysa er einnig há eins og sést á pví að tilkynningar til TR vegna slysa á sjómönnum ná $7 \%$ af heildarfjölda starfandi sjómanna árlega og um 45 sjómenn eru metnir til örorku á ári eftir slys. Samkvæmt uppgjöri TR á árunum 2001-2005 voru sjómenn 21\% af öllum peim sem metnir voru með 10-49\% örorku eftir slys. ${ }^{17}$ Öll slys hjá sjómönnum á að tilkynna til TR með sérstöku eyðublaði en tryggingarbótaleg staða sjómanna er sú sama og annarra launpega. Útgerðarfélög greiða sjómönnum áfram laun en fá síðan endurgreitt frá TR ólíkt pví sem á við hjá öðrum starfsstéttum. Prátt fyrir háa tíðni slysa og fjölda innlagna á sjúkrahús virðist ekki vera algengt að sjómenn slasist lífshættulega samkvæmt áverkaskori og enginn peirra sem lögðust inn á Landspítala lést af völdum áverkanna á rannsóknartímabilinu.

Svo virðist sem verkefni manna um borð 
valdi slysunum frekar en veður, sjólag eða birta. Athyglisvert er að flest slys virðast eiga sér stað við góðar aðstæður, lítinn vind, tiltölulega lítinn sjó, í engri úrkomu og um hábjartan dag. Ætla mætti að skýringin væri sú að flestir væru við vinnu í góðu veðri en staðreyndin er sú að flest slys verða um borð í togurum sem eru að veiðum í öllum veðrum. Ekki er ljóst af hverju slysatíðni nær hámarki seinni part dags en hugsanlega skiptir par máli preyta sem fylgir vaktavinnukerfi. Íslensk rannsókn á áhrifum hvíldar á heilsu og öryggi sjómanna bendir til pess að meirihluti sjómanna vakni preyttir og að pað komi fram svefngloppur í vöku bæði seinni part nætur og seinni part dags. ${ }^{18}$ Mikilvægt er pví að stuðla að pví að sjómenn hafi góða hvíldaraðstöðu og fái nægilega hvíld á milli vinnulota. Slysin verða helst á vetrarmánuðum sem væntanlega tengist pví að pá eru flestir úthaldsdagar. Úthaldsdagar eru að jafnaði færri í desember en aðra mánuði ársins og pað skýrir sennilega lægri slysatíðni pann mánuð.

Nánast öll banaslys og mikill meirihluti annarra slysa eiga sér stað á fiskiskipum. Slys um borð í kaupskipum virðast fátíð, en ekki fengust upplýsingar um fjölda starfandi sjómanna á kaup-

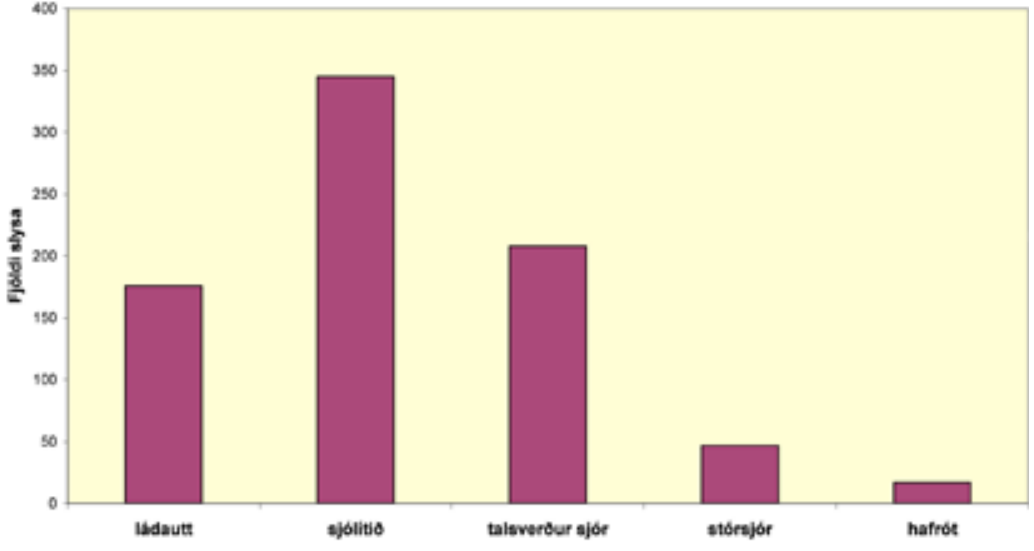

Mynd 2. Sjólag pegar slys varð. Myndin sýnir dreifingu slysa eftir pví hvernig sjólag var pegar slys átti sér stað. Hér eru ekki tekin með banaslys. Meirihluti slysa verður í lygnum sjó. Ládautt = engar gárur sjást.

Sjólítið = ölduhceð metin 0,1-0,5 m.

Talsverður sjór $=$ ölduhœe metin 1,25-2,5 m.

Stórsjór $=$ ölduhceð metin 6-9 m.

Hafrót $=$ ölduhceð metin 9-14 m.

skipum par sem pau eru nánast öll skráð erlendis og skipverjar pví ekki lögskráðir hérlendis.

Ætla mætti að reynslulitlir sjómenn lentu frekar í slysum en peir reyndari, en athyglisvert er að 69\% slysa verða hjá sjómönnum með meira en

Tafla IV. Tegund áverka. Fjöldi slysa flokkast eftir tegund áverkans. Banaslys eru ekki tekin með. Meira en helming áverka má rekja til höggs við árekstur eða fall.

\begin{tabular}{|c|c|c|c|c|c|c|}
\hline \multirow[t]{2}{*}{ Orsök áverka } & \multicolumn{2}{|c|}{ Fiskiskip } & \multicolumn{2}{|c|}{ Önnur skip } & \multicolumn{2}{|c|}{ Öll skip } \\
\hline & Fjöldi & Hlutfall & Fjöldi & Hlutfall & Fjöldi & Hlutfall \\
\hline högg, skellur vegna árekstrar & 215 & $30 \%$ & 28 & $26 \%$ & 243 & $29 \%$ \\
\hline högg, árekstur við hlut á hreyfingu & 158 & $22 \%$ & 18 & $17 \%$ & 176 & $21 \%$ \\
\hline högg, árekstur við kyrrstæðan hlut & 51 & $7 \%$ & 10 & $9 \%$ & 61 & $7 \%$ \\
\hline árekstur, annar & 6 & $1 \%$ & & & 6 & $1 \%$ \\
\hline högg, skellur vegna falls & 161 & $22 \%$ & 35 & $32 \%$ & 196 & $24 \%$ \\
\hline fall á einum fleti, hrösun & 67 & $9 \%$ & 11 & $10 \%$ & 78 & $9 \%$ \\
\hline fall á einum fleti, skrikun & 48 & $7 \%$ & 7 & $6 \%$ & 55 & $7 \%$ \\
\hline lágt fall eða stökk & 14 & $2 \%$ & 5 & $5 \%$ & 19 & $2 \%$ \\
\hline hátt fall eða stökk & 14 & $2 \%$ & 3 & $3 \%$ & 17 & $2 \%$ \\
\hline fall í eða úr stiga & 14 & $2 \%$ & 7 & $6 \%$ & 21 & $3 \%$ \\
\hline fall, annað & 4 & $1 \%$ & 2 & $2 \%$ & 6 & $1 \%$ \\
\hline kramning & 130 & $18 \%$ & 12 & $11 \%$ & 142 & $17 \%$ \\
\hline skurður, höggning, sögun & 77 & $11 \%$ & 6 & $6 \%$ & 83 & $10 \%$ \\
\hline stunga, önnur innprenging & 41 & $6 \%$ & 2 & $2 \%$ & 43 & $5 \%$ \\
\hline brád ofáreynsla líkamans & 35 & $5 \%$ & 17 & $16 \%$ & 52 & $6 \%$ \\
\hline bráð ofáreynsla við að lyfta. & 10 & $1 \%$ & 6 & $6 \%$ & 16 & $2 \%$ \\
\hline bráð ofáreynsla við að draga, toga, ýta & 8 & $1 \%$ & 3 & $3 \%$ & 11 & $1 \%$ \\
\hline ofáreynsla við annað & 17 & $2 \%$ & 8 & $7 \%$ & 25 & $3 \%$ \\
\hline aðskotahlutur & 34 & $5 \%$ & 3 & $3 \%$ & 37 & $4 \%$ \\
\hline aðskotahlutur í auga & 27 & $4 \%$ & & & 27 & $3 \%$ \\
\hline aðskotahlutur annað & 7 & $1 \%$ & 6 & $6 \%$ & 13 & $2 \%$ \\
\hline annað/ótilgreint & 24 & $3 \%$ & & & 24 & $3 \%$ \\
\hline samtals & 717 & & 109 & & 826 & \\
\hline
\end{tabular}


fimm ára starfsreynslu. Par sem flest slysin verða við töku á veiðarfærum má ætla að reyndari sjómenn séu frekar hafðir við pau störf en peir sem óreyndari eru. Ekki er hægt að útiloka að með tímanum verði menn kærulausir eða gleymi að gæta að sér. Athygli peirra reyndari, sem oftar hafa lent í erfiðum aðstæðum, slaknar ef til vill pegar vel viðrar og aðstæður eru góðar. Störf við meðferð veiðarfæra valda flestum slysum og samrýmist pað niðurstöðum rannsókna frá Frakklandi ${ }^{3}$ og Danmörku. ${ }^{19}$ Togveiðar virðast vera hættulegustu fiskveiðarnar par sem 51\% slysa verða við slíkar veiðar en einungis $4 \%$ slysa sem koma til meðferðar á Landspítala verða á nótaveiðum.

Skipting slysa eftir orsökum í pessari rannsókn er nánast eins og í niðurstöðum rannsóknar á orsökum 576 slysa á fiskimönnum sem komu til meðferðar á slysadeild í Esbjerg í Danmörku 1990$1997 .{ }^{20}$ Staðsetning áverka á líkamann er mjög svipuð í pessari rannsókn og í franskri rannsókn tímabilið 1996-2001³ og norskri rannsókn tímabilið 1991-1996. ${ }^{21}$ Algengast er að áverkar séu á útlimum og par af eru áverkar á höndum algengastir.

Í pessari rannsókn var leitað eftir upplýsingum úr premur mismunandi skrám sem fært er 1 eftir mismunandi skilyrðum. Verður pað að teljast helsti veikleiki rannsóknarinnar. Nokkuð öruggt er að öll banaslys eru tilkynnt til rannsóknarnefndar. Samkvæmt lögum ber skipstjóra, útgerðarmanni, Tilkynningarskyldu íslenskra skipa, Landhelgisgæslu, lögregluyfirvöldum eða öðrum sem fregna af banaslysi á sjó skylda til að tilkynna og ganga úr skugga um án undandráttar að rannsóknarnefnd sjóslysa fái vitneskju um slysið.22 Slys önnur en banaslys eru einnig tilkynningaskyld til nefndarinnar en pað sýnir sig að aðeins $24 \%$ peirra slysa sem tilkynnt voru til TR á tímabilinu sem rannsóknin fjallar um voru jafnframt tilkynnt rannsóknarnefnd sjóslysa. ${ }^{23}$ Brýnt er að bæta upplýsingaflæði til nefndarinnar.

Tilkynningar um slys berast TR af öllu landinu og má pví ætla að sú skráning gefi besta mynd af tíðni slysa hjá sjómönnum. Tilkynning til TR er háð peim skilyrðum að slysið sé bótaskylt og er pað góður hvati til að skráning fari fram. Óljóst er hversu mörg minniháttar slys eru ekki tilkynnt og rannsóknin nær pví ekki til allra slysa á sjó, en gera má ráo fyrir pví að alvarleg slys séu ávallt tilkynnt.

Á slysa- og bráðadeild Landspítala eru skráðar allar komur vegna slysa, bæði minni- og meiriháttar áverkar. Ekki er vitað hversu margir sem lenda í slysum á sjó leita til annarra sjúkrahúsa eða heilbrigðisstofnana á Íslandi, nema pað sé tilkynnt til TR eða rannsóknarnefndar. Pannig er norræna slysaskráin ekki lýðgrunduð, en kosturinn við pessa skrá er að hún er framsýn og í henni felast miklar upplýsingar um aðstæður pegar slys verða. Starfsfólk slysa- og bráđadeildar skráir staðlaðar upplýsingar frá sjúklingnum við komu en gæði skráningar verða alltaf háð svarhlutfalli, nákvæmni skrásetjara og peim sem veitir upplýsingarnar.

Í pessari rannsókn hafa pessar prjár skrár verið teknar saman til að fá heildræna mynd af slysatíðni hjá sjómönnum en í pví felst ákveðin óvissa. Auðveldara væri að gera sér grein fyrir umfangi vandamálsins ef til væri ein slysaskrá á Íslandi með vel skilgreindum inntökuskilyrðum, breytum og góðu eftirliti með að tilkynningarskyldu væri sinnt. Slysaskrá Íslands gefur möguleika á slíkri skráningu en pá purfa sjúkrahús og heilsugæslustöðvar að senda inn tilkynningu um sjóslys úr Sögu, sjúkraskrárkerfi viðkomandi stofnunar. Upplýsingar um sóknardaga, úthald skipa á sjó og fjölda sjómanna um borð pyrfti að tengja við skráninguna. Hafin er gerð samræmds gagnagrunns um slys á sjó að tilstuðlan Siglingastofnunar Íslands í samvinnu við Rannsóknarnefnd sjóslysa. Par sem flest slys hjá sjómönnum verða við góðar ytri aðstæður og hjá mönnum með fremur langa starfsreynslu er frekari rannsókna pörf á vinnuaðferðum og öryggisráðstöfunum um borð. Sérstaklega á petta við um borð í fiskiskipum par sem starfið virðist vera mjög áhættusamt. Nauðsynlegt er að reyna að bæta vinnuaðferðir og fækka pannig slysum í pessari starfsstétt.

\section{Ályktun}

Eins og hjá öðrum pjóðum er tíðni vinnuslysa hjá íslenskum sjómönnum há, bæði banaslysa og annarra slysa. Slysin verða oftast við góðar ytri aðstæður og má oftast rekja pau til vinnuaðferða. Bæta parf skráningu pessara slysa á landsvísu með samræmingu skráningaraðferða og með pví að allar sjúkra- og heilbrigðisstofnanir innleiði NOMESCO slysaskráningakerfi. Pá parf einnig að rannsaka nánar vinnulag sjómanna svo finna megi orsakir hinna tíðu slysa og beita forvörnum markvisst.

\section{Pakkir}

Hinar bestu pakkir fá Gísli Viggósson og Jón Bernódusson hjá Siglingastofnun Íslands fyrir hvatningu til verksins og stuðning. Ingibjörg Richter á upplýsinga- og tæknisviði Landspítala fær miklar pakkir fyrir aðstoð við öflun gagna. 


\section{Heimildir}

1. Útflutningur og útflutningsframleiðsla sjávarafurða 2007. Hagtíðindi, Hagstofa Íslands 2008.

2. Driscoll TR, Ansari G, Harrison JE, Frommer MS, Ruck EA Traumatic work related fatalities in commercial fishermen in Australia. Occup Environ Med 1994; 51: 612-6.

3. Chauvin C, Le Bouar G. Occupational injury in the french sea fishing industry: A comparative study between the 1980s and today. Accident Analysis Prevention 2007; 39: 79-85.

4. Roberts SE. Occupational mortality in british commercial fishing, 1976-95. Occup Environ Med 2004; 61: 16-23.

5. Hansen HL, Nielsen D, Frydenberg M. Occupational accidents aboard merchant ships. Occup Environ Med 2002 59: 85-91.

6. O'Connor PJ, O'Connor N. Work-related maritime fatalities. Accid Anal Prev 2006; 38: 737-41.

7. Rafnsson V, Gunnarsdóttir H. Fatal accidents among Icelandic seamen: 1966-86. Br J Ind Med 1992; 49: 694-9.

8. Pétursdóttir G, Hjörvar T, Snorrason H. Fatal accidents in the Icelandic fishing fleet 1980-2005. Int Marit Health 2007; 58: 47-58.

9. Aasjord HL. Tools for improving safety management in the Norwegian fishing fleet occupational accidents analysis period of 1998-2006. Int Marit Health 2006; 57: 76-84.

10. Work-related accidents in the EU - the statistical picture (1998-1999). European Agency for Safety and Health at Work EU 2001

11 Baker SP, O`Neill B, Haddon W Jr, Long WB. The Injury Severity Score: A method for describing patients with multiple injuries and evaluating emergency care. J Trauma 1974; $14: 187-96$
12. American Association for the Advancement of Automotive Medicine: The abreviated injury scale. Des Plaines, III: American Association for the Advancement of Automotive Medicine, 1990 revision, update 1998.

13. www.hagstofa.is/hagtolur/Laun,-tekjurogvinnumarkadur/ vinnumarkadur.

14. Stöðugleikinn skiptir sköpum. Til sjávar. Fréttabréf Siglingastofnunar 2009; 13: 10

15. Ársskýrsla 2004. Vinnueftirlit ríkisins 2005: 22.

16. Ársskýrsla 2005. Vinnueftirlit ríkisins 2006: 25.

17. Tryggingarstofnun ríkisins. Fjöldi öryrkja sem metnir hafa verið 10-49\% öryrkjar í kjölfar slyss 1984-2005. www.tr.is / media/gjaldskrar/Tafla4.4_net.XLS Maí 2008.

18. Lovísa Olafsdóttir. Áhrif hvíldar á heilsu og öryggi sjómanna. Rannsókn á íslenskum sjómönnum. Samgönguráðuneytið maí 2004 .

19. Jensen O. Injury risk at the work processes in fishing: A case-referent study. European Journal of Epidemiology 2006;21:521-527.

20. Jensen OC. Non-fatal occupational fall and slip injuries among commercial fishermen analyzed by use of the NOMESCO injury registration system. Am J Ind Med 2000;37:637-644.

21. Bull N, Riise T, Moen BE. Occupational injuries to fisheries workers in Norway reported to insurance companies from 1991 to 1996. Occup Med (Lond) 2001;51:299-304.

22. Lög um rannsókn sjóslysa nr. 80/2000.

23. Rannsóknarnefnd sjóslysa. Skýrsla Rannsóknarnefndar sjóslysa fyrir árið 2006. 2007;:30

\section{Fatal accidents and non-fatal injuries amongst seamen in Iceland 2001-2005}

Objectives: This study aims at getting a comprehensive view of the incidence, nature and circumstances leading up to injuries in Icelandic waters in 2001-2005.

Material and methods: The NOMESCO database at Landspitali University Hospital registers prospectively accidents at sea treated in the Emergency Department, including circumstances leading to the accident, vessel type, experience, task being performed, weather conditions etc. The Icelandic Marine Accident Investigation Board provided data on fatal injuries, and additional information on injuries at sea was collected from the Social Insurance Administration (SIA).

Results: Of 17 fatal accidents occurring in 2001-2005

14 were work related which amounts to 54/100.000 seamen/year. The SIA received 1787 injury reports (7\% of registered seamen), 826 sought assistance at Landspitali, 52 were admitted with an average injury severity score of $5.5(1-16)$ and no ensuing fatalities. Most accidents occurred on fishing vessels (87\%), $51 \%$ thereof on trawlers. Experienced fishermen are most commonly injured, working on deck in daylight and stable weather. Conclusions: Fatalities have declined steadily in the last two decades, yet $7 \%$ of registered fishermen sustain injuries each year. These occur amongst experienced fishermen in good external conditions, which calls for revision of safety procedures on board.

Sigvaldason K, Tryggvason F, Petursdottir G, Snorrason H, Baldursson B, Mogensen B.

Fatal accidents and non-fatal injuries amongst seamen in Iceland 2001-2005. Icel Med J 2010; 96: 29-35.

Key words: Accidents at sea, fishermen, seafarers, fatalities, injury severity score.

Correspondence: Kristinn Sigvaldason, krisig@landspitali.is

Barst: 14. júní 2009, - sampykkt til birtingar: 25. nóvember 2009. 